\title{
Uyum Performansı Ölçeğinin Türkçe Uyarlaması: Geçerlik ve Güvenirlik Çalışması
}

\author{
Ferda ÜSTÜN \\ Nevşehir Hacı Bektaş Veli Üniversitesi, İşletme Bölümü \\ ferdakervanci@gmail.com \\ ORCID ID: 0000-0002-7397-8048 \\ Şı Mehmet BÜYÜKBAȘ \\ Nevşehir Hacı Bektaş Veli Üniversitesi, Sosyal Bilimler Enstitüsü, Doktora Öğrencisi \\ sih_mehmet@hotmail.com \\ ORCID ID: 0000-0003-2234-2223
}

\begin{tabular}{lrr} 
Araştırma Makalesi & DOI: $10.31592 /$ aeusbed.687017 \\
\hline Geliş Tarihi: 14.02 .2020 & Revize Tarihi: 16.07 .2020 & Kabul Tarihi: 17.07 .2020
\end{tabular}

\section{Atıf Bilgisi}

Üstün, F. ve Büyükbaş, Ş. M. (2020). Uyum performansı ölçeğinin Türkçe uyarlaması: Geçerlik ve güvenirlik çalışması. Ahi Evran Üniversitesi Sosyal Bilimler Enstitüsü Dergisi, 6(2), 637-656.

\section{ÖZ}

Uyum performansı, çalışanın değişen iş yapılarına, koşullarına ve iş rollerine uygun şekilde; öngörülen ya da gerçekleşen değişiklikleri esas alarak davranışlarını değiştirebilme becerisidir. Değişim ve dönüşümlerin hızı göz önünde bulundurulduğunda uyum ve uyum performansı kavramının önemi herkesçe bilinmesine rağen kavramın literatürde görece az çalışıldığı söylenebilir. Bu çalışmanın amacı, Charbonnier-Voirin ve Roussel (2012) tarafından geliştirilmiş olan uyum performansı ölçeğinin Türkçe uyarlamasının yapılmasıdır. Uyum performansı kavramına ilişkin ayrıntılı bir literatür taraması sunarak; yönetici ve uygulayıcıları alternatif ve yeni bir performans değerleme kriteri ile tanıştırmak araştırmanın diğer amaçları arasında yer almaktadır. Araştırmada kullanılan veriler Kayseri organize sanayi bölgesi imalat sanayinde faaliyet gösteren iki özel işletmede görev yapan 192 çalışandan elde edilmiştir. Verilerin analizinde açımlayıcı faktör analizi (AFA), doğrulayıcı faktör analizi (DFA), yapı geçerlilik analizi ve iç tutarlılık analizleri kullanılmıştır. Araştırma sonucunda Charbonnier-Voirin ve Roussel'in (2012) geliştirdiği ve orijinal ölçekte acil durum adaptasyonu, kişilerarası uyum, yaratıcılık, eğitim çabaları ve strese uyum alt boyutlarından oluşan uyum performansı ölçeğinin; bu çalışma ile acil durum adaptasyonu, kişilerarası uyum, yaratıcılık, eğitim çabaları olarak dört boyutlu yapısı doğrulanmıştır. Bu anlamda dört boyutlu uyum performansı ölçeğinin Türkiye'de gelecekte yapılacak çalışmalarda kullanılabilecek güvenilir ve geçerli bir ölçüm aracı olduğu ortaya konulmuştur.

Anahtar Kelimeler: Uyum performans1, Türkçe uyarlama, güvenirlik, geçerlik.

\section{Adaptation of The Adaptive Performance Scale to Turkish: A Validity And Reability Study}

\begin{abstract}
Adaptive performance is the ability of the employee to change his/her behavior in line with changing business structures, conditions and job roles, based on predicted or actual changes. Considering the speed of changes and transformations, although the importance of the concept of adaptation and adaptive performance is known to all, it is possible to say that the concept has been studied relatively little in the literature. The aim of this study is to make Turkish adaptation of the adaptive performance scale developed by Charbonnier-Voirin and Roussel (2012). Presenting a detailed literature review on the concept of adaptive performance, so introducing managers and practitioners to an alternative and new performance evaluation criteria are among the other aims of the research. The data used in the study were obtained from 192 employees working in two private enterprises operating in the manufacturing industry of Kayseri Organized Industrial Zone. In the analysis of the data, exploratory factor analysis (EFA), confirmatory factor analysis (CFA), construct validity analysis and internal consistency analyzes were used. As a result of the research, the adaptive performance scale developed by Charbonnier-Voirin and Roussel (2012) that originally consists the emergency adaptation, interpersonal adjustment, creativity, training efforts, and stress adaptation sub-dimensions, the fourdimensional structure of the scale (emergency adaptation, interpersonal adaptation, creativity and training efforts) has been confirmed in the study. In this sense, the four-dimensional adaptive performance scale has been demonstrated to be a reliable and valid measurement tool that can be used in future studies in Turkey.

Keywords: Adaptive performance, Turkish adaptation, validity, reability.
\end{abstract}

\section{Giriş}

Günümüzün teknolojik gelişmeleri ve sürekli değişen çevre şartları sonucu oluşan kaotik yönetim anlayışı yeni iş durumlarına uyumu zaruri hale getirmektedir. Özellikle bilgiyi elde etme, 
kategorize etme, uygun şekilde kullanabilme ve gerektiğinden yeniden kullanım için saklayabilmeye ilişkin becerilerdeki ve teknolojideki büyük gelişmeler ile iş performansının belirleyicileri de önemli ölçüde değişmiştir (Hesketh ve Neal, 1999, ss. 28-29). İş dinamiklerindeki belirsizlik ve öngörülemezlik, örgütlerin sosyal-ekolojik sistem olarak gösterdiği karmaşık davranışlar yöneticilerin karar alma, eğitim, iş birliği vb. konularda uyum perspektifli bir yönetim anlayışı benimsemelerini zorunlu kılmıştır (Allen, Fontaine, Pope, Garmestani, 2011, s. 1339).

İşletmelerin küresel dünyamızda rekabet üstünlügü elde edebilmesi ve bunu sürdürebilmesi sahip oldukları insan kaynaklarını etkin bir şekilde kullanabilmelerine bağlıdır (Özdemir, 2019, s. 237). İnsan kaynaklarının işe alım sürecinden başlayarak tüm örgütsel süreçlerde kendisini hissettiren en önemli kriterlerinden biri olan uyum, örgütlerin stratejik amaç ve hedeflerine ulaşmasında da son derece önemlidir. İșletmeler ayakta kalabilmek için sürekli kendini yenilemek ve değișen koşullara ayak uydurmak zorundadırlar (Çetinkaya ve Gülbahar, 2019, s. 349). Değişim, belirsizlik, karmaşa, stres vb. zor durumlar karşısında gerekli esnekliği gösterebilmeyi ifade eden uyum kavramı (Pulakos, 2009 , s. 154) sosyal bilimler açısından bireylerin sosyal ve iş çevrelerinde meydana gelen değişikliklere kendilerini ayarlama yetenekleri olup başarının da kilit faktörünü oluşturmaktadır. Pazara ve müşteriye ilişkin değişimler, kaynak kıtlığı, artan rekabet sonucu gerçekleşen birleşmeler, küçülme, dış kaynak kullanımı vb. yeni stratejik politikaların uygulanması sonucu ortaya çıkan farklı örgütsel yapı ve koşullar uyum kavramının örgütler açısından önemini gün geçtikçe artırmaktadır (Ployhart ve Bliese, 2006, s. 5).

Günümüzde bir organizasyon bünyesinde maddi kaynaklar ne kadar iyi olursa olsun insan kaynağı yeterli etkinliğe sahip değilse başarı olasılığı çok düşük olacaktır. Temel amacı verimliliği artırmak, iş yaşamının niteliğini yükseltmek ve bu sayede rekabet üstünlüğü kazanmak olan insan kaynakları yönetiminin en önemli görevlerinden biri de çalışanların performansını değerlendirmektir (Uyargil, Adal, Ataay, Acar, Özçelik, Dündar, Sadullah ve Tüzüner, 2009). Ancak araştırma ve pratik uygulamalarda performans değerlendirmenin geniş bir bakış açısıyla, psikometrik ve çok boyutlu bir şekilde ele alınması noktasında ciddi bir eksiklik söz konusudur (Charbonnier-Voirin ve Roussel, 2012, s. 280). Teori ve uygulamada bireysel performansı tanımlayan görev performans1 ve bağlamsal performans olarak iki tür performanstan bahsedilmektedir (Jawahar ve Carr, 2007). Görev performans1; bireyin bilgi, beceri, yetenek ve motivasyonunu iş tanımları gibi belirlenen davranışlara yönelterek işlevini yerine getirmesidir (Campbel, 1999). Bağlamsal performans ise organizasyonun teknik merkezi işlevini yerine getirmesini sağlayan faaliyetlere ek olarak; çalışma ortamının organizasyonel, sosyal ve psikolojik havasını zenginleştiren çalışmalara işaret etmektedir (Ünlü vd., 2009, s. 76). Yukarıda da değinildiği gibi teknolojik yeniliklerden doğan değişim hızlı adımlarla ilerledikçe örgütlerde değişimle başa çıkmak ve yenilikleri öğrenmek önemli bir hal almaktadır. $\mathrm{Bu}$ gelişmeler altında performansı mutlak bir şekilde değerlendirmek yerine iş taleplerindeki değişime odaklanmak daha doğru olacaktır.

$\mathrm{Bu}$ doğrultuda görev ve bağlamsal performanstan farklı bir performans boyutu olarak ele alınan uyum performansi; yeni görevleri öğrenme, onlara yaklaşma konusundaki güven, esneklik ve değişimle baş edebilme kapasitesi olarak tanımlanmıştır (Hesketh ve Neal, 1999, ss. 46-47). Değişken ve tahmin edilmesi zor çevre şartlarında çalışanların etkinlik ve verimliliklerini sürdürebilmesi için belirsizlik karşısında toleranslı ve çok yönlü bir uyum sağlama yeteneğine gereksinimleri vardır (Ilgen ve Pulakos, 1999, s. 14; Kozlowski ve Bell, 2003, s. 4; Pulakos, Arad, Donovan ve Plamondon, 2000, s. 612). Örgütlerin fark yaratan ve taklit edilmesi imkânsız bir kaynağı olarak değerlendirilen çalışanların farklı ve yeni koşullara uyum yeteneği, örgütlerin rekabet yetenekleri ve varlıklarını devam ettirme gücü üzerinde de büyük öneme sahiptir. Uyargil' in de (2013, s. 212) ifade ettiği gibi işletmelerde rekabet avantajı sağlayan en önemli kaynak insandır ve çalışanların performanslarının bütüncül bir yaklaşımla değerlendirilmesi örgütsel hedeflere ulaşma açısından büyük önem arz etmektedir.

Örgütlerde benimsenen insan kaynakları uygulamaları çalışanların gösterdiği performansın gelişimine doğrudan katkı sağlamaktadır. Çalışanların iş güvencesinin sağlanması, motive edilmesi, bireysel ve örgütsel amaçların bütünleştirilmesi, çalışanlar arasında bilgi paylaşımı ve şeffaflığın 
sağlanması ayrıca örgütte kalma niyetleri benimsenen bu uygulamaların etkinliğine bağlidır (Ahmad ve Schroeder, 2003, ss. 20-21). Örgütlerin stratejik amaç ve hedeflerine ulaşmasında büyük etki ve güce sahip olan insan kaynağının etkinlik ve verimlilik ilkeleri doğrultusunda çalışmasına yardımcı olan uyuma ilişkin yetenek ve beceriler algılanan olumlu örgütsel uygulama ve süreçlerle hayat bulacaktır. Yine bireyde başlayan uyum becerisi, takımlara yansıyacak, takımlar ise örgütsel bir uyum çatısı altında başarıyı yakalayacaktır.

Örgütlerde sürekli değişen bilgi ve beceri gereksinimlerine rağmen çalışanların uyum performanslarının nasıl artırılacağı alan yazında yeterince incelenmemiş bir konudur (Champbell, 1999, s. 402). Bilgi ve iletişim teknolojilerindeki gelişmelere paralel olarak global piyasalarda yeniliğin hızla yayılması sonucu üretim döngüleri de daha kısa sürede tamamlanmaya başlamıştır (LePine, Colquitt ve Erez, 2000, s. 564). Bu değişim süreci lider ve yöneticileri; yetenekli personeli elde tutma adına değişime uygun tepki göstermeye zorlamaktadır (Grotto, Hyland, Caputo ve Semedo, 2017, s. 464). Bu doğrultuda araştırmacı ve uygulayıcıların uyum performansına ilgisinin arttı̆̆ ve konuya ilişkin kavramsal ve amprik çalışmaların sayısının çoğaldığı görülmektedir (CharbonnierVoirin ve Roussel, 2012; Joung, Hesketh ve Neal, 2006; Pulakos vd.,2000; Pulakos vd., 2002; Pulakos, Dorsey ve White, 2006; Şahin ve Gürbüz, 2014).

Uyum performansının öncül ve ardıllarını belirlemeye yönelik yapılan çalışmalarda kavramın çok farklı değişkenler ile birlikte incelendiği görülmektedir. Bu doğrultuda kavrama ilişkin ayrımı ortaya koyabilmek ve kendi içerisinde konu bütünlüğü sağlamak amacıyla literatür taraması bireysel, takım ve örgüt düzeyinde yapılmıştır. Uyum performansını daha çok bireysel değişkenler ile birlikte ele alıp inceleyen çalışmalar literatürün oldukça büyük bir bölümünü oluşturmaktadır. Bu çalışmaların bir kısmı uyum performansının yordayıcılarını belirlemeye yönelik iken; bir kısmı ise kavramın çeşitli değişkenler ile ilişkilerini tespit etmeye yöneliktir. Bu çalışmalardan bir kısmı aşağıdaki gibidir:

Pulakos vd., (2006) bireysel farklılıkların Pulakos vd. (2000) tarafindan tespit edilen uyum performansının sekiz boyutunun yordayıcısı olduğunu iddia etmiş ve bu doğrultuda 17 kişiden oluşan endüstriyel ve örgütsel psikolog grubu üzerinde bir araştırma gerçekleştirmiş̧lerdir. Araştırma sonucunda kişisel özellikler arasında yer alan bilişsel yetenek, pratik zeka, orijinallik, duygusal dayanıklılık, açıklık, bilişsel esneklik, başarı motivasyonu, işbirlikçilik, sosyallik, sosyal zeka ve fiziksel yetenek değişkenlerinin her birinin farklı uyum performansı boyutlarının yordayıcısı olduğu tespit edilmiştir (Pulakos vd., 2006, s. 53). Yine Huang vd. 'nin (2014) gerçekleştirdikleri meta-analiz çalışması kişilik özelliklerinden hırs ve duygusal dengenin uyum performansının en önemli yordayıcılarından olduğuna işaret etmektedir (Huang vd., 2014, s. 162).

Allworth ve Hesketh (1999 s. 105) gerçekleştirdikleri çalışmada kişisel bilgi boyutu olan değişim deneyimi ile bilişsel yetenek boyutları olan soyut ve sayısal düşünce, yazışma hızı ve kesinlik (geçerlilik) ile uyum performansi; Kozlowski vd. (2001 s. 17) öğrenme oryantasyonu, akademik kabiliyet, bildirilen bilgi, bilgi yapıs1, eğitim performans1, kendine güven ve uyum performans1 arasında pozitif ve anlamlı ilişkiler tespit etmiş̧tir. Benzer şekilde Han ve Williams da (2008 s. 671) kişisel seviyede uyum performansı ile sürekli ve takım öğrenme iklimi, yeni fikir ve yüksek beklenti arasında; Chen, Thomas ve Wallace (2005 ss. 833-834) ise kişisel seviyede rol bilgisi, öz-yeterlilik, hedef seçim ve hedef çaba aktiviteleri ile uyum performansı arasında pozitif ve anlamlı ilişkiler tespit etmiştir. Ayrıca araştırmacılar bu anlamlı ilişkinin kişisel seviyede takım seviyesinden daha güçlü olduğunu belirtmiştir. Benzer şekilde Griffin ve Hesketh (2003 s. 71) uyum performansı ile iş gerekleri, öz-yeterlilik, yeni deneyimlere açıklık ve değişimi kavrama yeteneği; Şahin ve Gürbüz (2014, s. 403) önceki vazife, kendine güven; Shoss, Witt ve Vera (2012, s. 917) beş faktör kişilik özelliklerinden deneyimlere açıklık arasında pozitif ve anlamlı ilişkiler tespit etmiştir. Stokes, Schneider ve Lyons (2010, s. 223) ise kavramı sübjektif ve objektif uyum performans1 olarak iki farkl1 açıdan değerlendirmiş, araştırma sonucunda hem sübjektif hem de objektif uyum performansının bilişsel yetenek ve öz-yeterlilik ile pozitif ve anlamlı ilişki içinde olduğunu belirtmiştir.

Yine yapılan çalışmalarda kültürel zeka ile uyum performansı arasında anlamlı bir ilişki (Oolders, Chernyshenko ve Stark, 2008, s. 148; Şahin ve Gürbüz, 2014, s. 403); deneyimler açılılı ile 
uyum performansı arasındaki ilişkide ise kültürel zekanın aracılık rolü üstlendiği tespit edilmiştir (Oolders vd., 2008, s. 155). Pulakos vd. (2002, s. 317) başarı motivasyonu ve bilişsel yeteneğin Drewery, Nevison, Pretti, ve Pennaforte (2017, s. 9) ise öz-yeterlilik, yaşam boyu öğrenme, rol anlayışı ve sosyal kabulün uyum performansını pozitif yönde ve anlamlı bir şekilde etkilediği sonucuna ulaşmıştır. Daha bağlamsal bir çalışma yürüten Joung, Hesketh ve Neal (2006, ss. 282-283) askerlere eğitimlerde dinletilen savaş hikâyelerinin onların uyum performansları üzerindeki etkisini belirlemeyi amaçlamış ve uyum performansını başarı hikâyelerinden daha çok başarısızlık hikayelerinin etkilediği sonucuna ulaşmıştır.

Günümüz modern örgütlerinin esnek ve dinamik yapıları ile takımlar ve takımların önemi de gün geçtikçe artmaktadır (Jundt, Shoss ve Huang, 2015, s. 67). Takımlar üyelerinin toplamından daha fazlasını ifade eder. Dolayısıyla kişisel sevide uyumdan daha çok takım seviyesinde uyuma gereksinim vardır (Pulakos, Dorsey ve White, 2006, s. 55). Bu bakımdan araştırmacıların uyum performansını takım seviyesinde inceleyerek açıklığa kavuşturulmamış noktaların aydınlatılmasına katk1 sunmaları elzemdir (Jundt, Shoss ve Huang, 2015, s. 67). Öyle ki Baard, Rench ve Kozlowski (2014, ss. 92-93) uyum performansı üzerine gerçekleştirdikleri bütüncül araştırmaları ile araştırmacılara yol göstermeyi, onları uyum performansı üzerine çalışmaları konusunda teşvik etmeyi ve kavramın kişisel ve takım seviyesinde çerçevesini belirlemeyi hedeflemişlerdir. Yine Pulakos vd.,(2006, s. 56) çalışmalarında bireysel uyumun takım uyumunun önemli yordayıcılarından biri olduğunu belirtmişler ve bu doğrultuda "Takım Uyum Performansı Modeli”ni geliştirmişlerdir. Modele göre bir çalışanın kişisel olarak yeni teknolojileri kullanabilme, iş yapma şekillerini ve prosedürleri öğrenebilme konusunda performansı yüksek olursa bu durum takım seviyesine de yansıyacak ve birey takım seviyesinde de yüksek uyum performansı gösterecektir. Benzer şekilde Han ve Williams (2008, s. 671) gerçekleştirdikleri çalışmada takım seviyesinde uyum performansı ile kişisel seviyede uyum performansı arasında pozitif ve anlamlı ilişkiler tespit etmiştir. Yukarıda da değinildiği gibi takım ve takım performansının her gün artan önemine karşın uyum performansını takım seviyesinde inceleyen çalışmaların sayısı oldukça yetersizdir. O çalışmalardan birkaçı şu şekildedir. Stokes, Schneider ve Lyons (2008, s. 12) çok kültürlü takımlar üzerinde gerçekleştirdikleri çalışmada öz-yeterliliğin sübjektif ve objektif uyum performansı üzerinde doğrudan ve pozitif yönlü, stres değerlendirmesinin ise dolaylı ve negatif yönlü etkiye sahip olduğunu tespit etmiştir. Bir diğer çalışmada ise Chen vd., (2005) takım seviyesinde kolektif yeterlilik ve aksiyon süreci ile uyum performansı arasında pozitif ve anlamlı ilişkiler tespit etmiştir.

Örgütlerin stratejik amaç ve hedeflerine ulaşabilmelerinde büyük önem arz eden uyum ve uyuma ilişkin yetenekler güç ve başarının odak noktasını oluşturmaktadır. Örgütlerin değişken ve belirsiz çevre koşullarında varlıklarını devam ettirebilmelerinin en önemli ve belirleyici kıstası niteliğindeki uyum performansı alan yazında çeşitli örgütsel değişkenler ile birlikte de incelenmiştir. Bu çalışmalardan bir kısmı aşağıdaki gibidir:

Monteiro (2015, s. 18) çalışmasında iş güvensizliği, işten ayrılma stresi ve tükenmişlik stresi ile uyum performansı arasında negatif ilişkiler tespit ederken; Açıkgöz (2015, s. 39) çalışanların bireysel uyum performanslarının işletmelerin örgütsel adaptasyon becerileri üzerinde pozitif ve anlamlı etkisi olduğu sonucuna ulaşmıştır. Ayrıca araştırma sonuçları bir işletmenin örgütsel adaptasyon kabiliyetinin o işletmenin geliştirdiği bir ürünün pazarda elde ettiği başarıya pozitif ve anlamlı etkisinin olduğu yönündedir. Lim Yoo, Kim ve Brickell (2017, s. 6) yaptıkları literatür taraması sonucunda öğrenen organizasyon ve dönüştürücü öğrenmenin uyum performansı üzerinde pozitif etkiye sahip olduğunu; ayrıca tespit edilen bu ikili ilişkide de öğrenme çevikliğinin aracılık rolü üstlendiğini tespit etmiştir. Charbonnier-Voirin ve Roussel (2012) ve Didin ve Ben-Roy (2017, s. 126) çalışmalarında bireysel uyum performansı ile dönüşümcü liderlik ve bağlamsal performans arasında pozitif ve anlamlı ilişkiler tespit etmişlerdir. Yine bu çalışmada liderlik ile uyum performansı arasındaki ilişkide güven ve değer örtüşmesinin pozitif yönlü aracıllk rolü tespit edilmiştir. Son olarak Jundt, Shoss ve Huang (2015, s. 67) uyum performansının sonuçlarını değerlendirdikleri çalışmalarında uyum performansının stresi azaltıp, iyi oluş halini artırdığını belirtmiştir. Araştırmacılar ayrıca uyum performansı yüksek olan çalışanların uzun süren, karmaşı görevlerle daha iyi baş edebileceklerini ileri sürmektedir. 
Öngörülen ya da gerçekleşen değişikliklerin davranışlara yansımasını ifade eden (Shoss, Witt, ve Vera, 2012, s. 911) uyum performansının önemi herkesçe bilinmesine karşın uyum ve uyum performansının literatürde görece az çalışıldığı görülmektedir. Bir yerde ne kadar çok değişiklik varsa o kadar da uyum gereksinimi var demektir. Uyum performansı ile ilgili yazındaki çalışmalardan görüleceği üzere kavram günden güne önem kazanmaktadır. Kavramın bireysel, takım ve örgütsel seviyede farklı açılardan genişleyen perspektifle alanda kendisine yer bulmaya devam edeceği söylenebilir. Bu çalışma ile yönetici ve uygulayıcıları alternatif ve yeni bir performans değerleme kriteri ile tanıştırmak amaçlanmaktadır. Bu sayede bağlamsal ve görev performansının yanında uyum performansının da göz önünde bulundurulduğu çok boyutlu ve bütüncül bir performans değerleme sistemi oluşturulabilinecektir. Ayrıca bu çalışma ile Türkçe literatüre; "Uyum Performansı" (adaptive performance) kavramının tanıtılarak kavrama ilişkin ayrıntılı bir literatür taraması sunmak ve uyum performansı ölçeğinin Türkçe güvenirlik ve geçerlilik çalışmasının yapılarak kavramın olası örgütsel çıktı ve sonuçlarla ilişkisini belirlemeye katkı sağlayacak yeni ve farklı bir enstrüman kazandırmak araştırmanın bir diğer amacını oluşturmaktadır. Bu sayede performansa daha geniş bir perspektifte bakılarak, görece ihmal edilmiş uyum performansı kavramına bilimsel çalışmalarda daha çok yer verilmesine yardımcı olmak hedeflenmektedir.

\section{Uyum Performansi}

Uyum performansı kavramı, çalışanın değişen iş yapılarına, koşullarına ve iş rollerine uygun şekilde gelecek odaklı bakış açısıyla ve kendi inisiyatifi doğrultusunda proaktif davranışlar göstermesidir (Koopmans, 2014, s. 37) ve kavram yetenek ve niyete göre daha kapsamlıdır. Uyum performansı öngörülen ya da gerçekleşen değişiklerin yansımasını davranışlarda göstermeyi ifade eder (Shoss vd., 2012, s. 911). Pulakos Pulakos, Arad, Donovan ve Plamondon'dan (2002, s. 299) aktarıldığ üzere hızla değişen teknoloji, yeni örgütsel yapılar ve birleşmeler ile küreselleşme eğilimli firma çalışanlarının da değişken ve belirsiz koşullara uyumunu zorunlu hale getirmektedir. $\mathrm{Bu}$ anlamda uyum performansı çalışanların bu değişikliklere uyum sağlama kapasitesi olarak tanımlanmış (Pulakos vd., 2000, s. 621) ve kavramın bireysel, takım ve örgütsel seviyede birçok farklı değişken ile ilişkili olduğu belirtilmiştir.

Uyum performans1 ilk kez Allworth ve Hesketh tarafindan (1999) "Construct-based biodata and prediction of adaptive performance" isimli bildiride ortaya atılmıştır. Ancak kavrama gösterilen temel ilgi Hesketh ve Neal (1999) tarafindan gerçekleştirilen "The Changing Nature of Performance" isimli çalışmaya dayanmaktadır. Araştırmacılar çalışmalarında teknolojinin performans üzerinde artan rolünü belirtirken iş çevresinde değişim ve uyumun da öneminin büyük ölçüde arttığını belirtmiştir. Pulakos vd. 'nin (2000) de ilgisini çeken kavram araştırmacıların "Adaptibility in the Workplace: Development of a Taxanomy of Adaptive Performance" isimli çalışmasında daha ayrıntılı bir şekilde ele alınmıştır. Adı geçen çalışma ile araştırmacılar kavramı keşfetmek, açılamak ve uyum performansı gereksinimlerini daha kesin çizgilerle betimlemeyi hedeflemişlerdir. Öyle ki Pulakos vd. 'nin (2000) bu çalışmayı gerçekleştirene kadar konuya ilişkin kesin bir görüşleri yoktur ve bu çalışma ile düşüncelerini netleştirmeye çalışmaktadırlar. Bu doğrultuda uyum performansı sinıflandırmasını geliştirmek için diğer modellerden aldıkları kavramsal çerçeveyi ortaya koyarak ve özellikle Champpbell McCloy, Oppler, ve Sager (1993) tarafından gerçekleştirilen " A Theory of Performance" isimli çalışmadan esinlenerek bir model geliştirmeyi istemişlerdir (Pulakos vd., 2000, s. 612). Ayrıca araştırmacılar uyum performansının, görev performansı ve bağlamsal performans gibi araştırmalarda yer verilen önemli bir performans boyutu olarak kabul edilmesini hedeflemişlerdir. Bu amaçla hem teorik hem de saha çalışması yardımıyla uyum performansı kavramını açıklamaya ve boyutlarını tespit etmeye çalışmışlardır (Pulakos vd., 2000, s. 612).

Uyum performansı ve görev performansı birbirlerine yakın olmasına rağmen aralarında temel bir farklılık bulunmaktadır. Uyum performansı işin gereklerinden kaynaklanan değişikliklere gösterilen tepkiye odaklanırken, görev performansı günlük gerçekleştirilen görevler ile ilgilenmektedir. Uyum performansı yüksek olan çalışanlar, sadece görev performansı yüksek olan çalışanlara göre işlerini daha kolay yürütmektedir. Ayrıca uyum performansı görev performansına göre daha kapsayıcı ve uluslararası geçerliliğe sahiptir (Allworth ve Hesketh, 1999, s. 98). Bu 
doğrultuda görev performansı ve bağlamsal performanstan tamamen farklı bir performans boyutu olarak ele alınan uyum performansı yeni görevleri öğrenme, onlara yaklaşma konusundaki güven, esneklik ve değişimle baş etme kapasitesi olarak tanımlanmıştır (Hesketh ve Neal, 1999, ss. 46-47). Teknolojik gelişmelere paralel olarak iş ihtiyaçlarında ortaya çıkan değişiklikler ve bu değişimlere uyum sağlama kapasitesi uyum performansının göstergesi olarak kabul edilebilmektedir (Pulakos vd., 2000, s. 621). Bu anlamda uyum performansı çalışanların değişikliklere başarıyla kanalize oluşunun bir kanıtıdır (Han ve Williams, 2008, s. 659). Bir yönetici veya çalışanın uyum performansının en belirleyici ölçütü ise örgütsel işleyişten veya çevreden kaynaklanan değişiklere tepki gösterme becerisidir (Karaevli ve Hall, 2006, s. 361) ki yüksek bireysel performanslar örgütsel düzeyde başarı, güç, büyüme, kar ve müşteri memnuniyeti gibi pozitif çıktıları da beraberinde getirecektir.

Tüm bu bilgiler 1şığında örgütlerde performansı değerlendirmenin yanı sıra çalışanların doğru performansı göstermelerinin yerinde ve zamanında üst düzeyde etkinlik göstermeleri adına önem arz ettiği söylenebilir. Üstelik değiş̧en çevresel ve örgütsel koşullara uyum yeteneği; örgütlerin stratejik amaç ve hedeflerini hızlı bir şekilde revize edebilmesine, problemlerin doğru ve hızlı bir şekilde algılanıp çözümlenmesine, farklı kültürel ve fiziksel koşullarla baş edilebilmesine yardımcı olmaktadır. $\mathrm{Bu}$ anlamda müşteri istek ve beklentilerini tatmin etmenin ötesine geçerek değer yaratmayı, küresel rekabet yeteneği ve başarısını hedefleyen örgütlerin uyuma ilişkin yeteneklerini geliştirmelerinin önemli olduğu söylenebilir.

\section{Uyum Performansının Boyutları}

Görev performansı ve bağlamsal performans gibi uyum performansı da çok boyutlu bir yapıya sahiptir (Sonnentag, Volmer ve Spychala, 2008, s. 430). Pulakos vd. (2000, s 2002) araştırmaları kapsamında gerçekleştirdikleri analizler sonucu uyum performansının tanımında yer verilen sekiz boyut tespit etmişlerdir. Bu boyutlar; acil durumlarla ve krizlerle başa çıkma, iş stresiyle başa çıma, problemleri yaratıcı bir şekilde çözme, belirsiz ve tahmin edilemeyen iş durumlarıyla ilgilenme, iş görevleri, teknolojileri ve süreçleri öğrenme, kişilerarası uyum gösterme, kültürel uyum gösterme ve işe bedenen uyum göstermedir (Pulakos vd., 2000, s. 617; Pulakos vd., 2002, s. 317).

Pulakos vd., (2000; 2002) tarafindan geliştirilmiş olan ölçeğin orijinali 132, kısa formu ise 68 ifadeden oluşmaktadır. Bu çalışmadan yola çıkarak birçok araştırmacı yeni ve farklı uyum performansı ölçeği geliştirmeyi denemiştir. Bunlardan Han ve Williams (2008) geliştirdikleri 12 ifadeli ölçekte orijinal ölçeğin dört boyutunu doğrulamıştır (Acil durumlarla başa çıkma, yaratıcı problem çözme, belirsiz ve tahmin edilemeyen iş durumlarıyla ilgilenme ve iş stresiyle başa çıkma). Ancak çalışmada yer alan uyum indeks değerlerinden bir kısmı standart değerlerin altında yer almaktadır. Yine Griffin ve Hesketh (2003) Pulakos vd. 'nin (2000; 2002) ölçeğini baz alarak örneklem grubuna göre 18 ile 20 ifade arasında değişen bir ölçek geliştirmeyi amaçlamıştır. Ancak bu çalışmada sadece ölçeğin iç tutarlılık katsayısı verilmiş olup ölçeğin boyutsallığı tartışılmamıştır. Bu çalışmaların dışında uyum performansını çeşitli bağlamlarda ele alan çalışmalarda mevcuttur. Örneğin Jong ve de Ruyter (2004), banka çalışanlarının uyum sağlama yeteneğini; Chen, Thomas ve Graig (2005) pilotların uyum performanslarını ölçmek adına ölçek geliştirmiştir. Charbonnier-Voirin, El Akremi ve Vandenberghe (2010) Pulakos vd. 'nin (2002) sekiz boyutlu ölçeğini kullandıkları çalışmada beş boyutlu bir ölçek yapısı tespit etmiştir. Ölçek kriz yönetimi, yaratıcı problem çözme, öğrenme, bireylerarası uyum ve stres yönetimi alt boyutlarından oluşmaktadır. Açıkgöz de (2015, s. 39) araştırmacıların çalışmalarında kullandığı bireysel uyum performansı ölçeğini çalışmasında kullanmış ve ölçeğin kriz yönetimi, yaratıcı problem çözme, öğrenme ve bireyler arası adaptasyon olarak dört boyuta sahip olduğunu tespit etmiştir. Charbonnier-Voirin ve Roussel (2012) yukarıda belirtilen tüm ölçüm araçlarını incelemiş ve çok boyutlu ve psikometrik olarak sağlam bir uyum performansı ölçeğinin eksikliğinden yola çıkarak literatürde kullanılmak üzere yeni bir ölçek geliştirme çabasına girişmiştir. 19 ifade ve beş boyuttan oluşan ölçek; yaratıcılık, acil durumlara uyum, kiş̧ilerarası uyum, eğitim çabaları ile stres yönetimi alt boyutlarından oluşmaktadır. Bu çalışmada Charbonnier-Voirin ve Roussel (2012, s. 285) tarafından geliştirilmiş en kapsamlı ve detaylı uyum performansı ölçeğinin Türkçe 'ye uyarlaması amaçlanmaktadır. Çalışmada araştırmacılar tarafından ortaya koyulan alt boyutlar aşağıdaki gibidir: 
Yaratıcılık: Çalışanların yeni yaklaşımlar geliştirerek sorunların ve karmaşık durumların üstesinden gelmesidir. Yaratıcılık proaktif yaklaşımlar göstermek, yenilikçi bir kültür geliştirmek ve öğrenen örgütler yaratmaktır (Robbins, Judge ve Erdem, 2012, s. 602). Çalışanlardan sadece yapmaları gereken işlere odaklanmaları beklenmemekte, onlardan sorunlar karşısında işlerini sanki kendi işyerlerinde çalışıyormuş gibi benimseyip; yeni ve yaratıcı çözümler bulmaları da istenmektedir (Monteiro, 2015, s. 28). Acil durum adaptasyonu: Acil durumlar hemen tepki verilmesi ve en kisa sürede karar alınması gereken süreçler olarak tanımlanmaktadır (Sezgin, 2003, s. 190). Bu noktada boyut kişilerin acil durumlara karşı öncelikleri belirleyebilme, derhal tepki verme ve acil durumla başa çıkabilme potansiyelini ifade etmektedir. Kişilerarası uyum: Çalışanların diğerlerine göre farklılık gösteren davranışlarını ve iş yapma stillerini diğer çalışanlara göre ayarlaması ve uyumlu hale getirmesidir. Uyum kişilerin davranışlarını grubun normlarına uygun hale getirmesidir. Uyumluluk kişinin işbirliğine yatkın ve güvenilir olduğuna vurgu yapar (Robbins, Judge ve Erdem, 2012, s. 664). Uyum gerçek olan ya da gerçek olduğu farz edilen grup etkisi ile inançlarda veya davranışlarda meydana gelen değişimdir (Yüksel, 2006, s. 189). Kişilerarası uyum amaçları gerçekleştirmek üzere diğer bireylerle etkileşimde olan kişilerin etkileşimi esnasında oluşan durumsal talepleri karşılamak için duygu, düşünce ve davranışları diğerlerine göre düzenleme yeteneğidir (Oliver ve Lievens, 2014, s. 5). Ë̆itim çabaları: İş görenlerin kişisel gelişimlerini sağlama amaciyla eğitim ve öğrenmeye yönelik çaba göstermesidir. Uyum performansı ile eğitim ve geliştirme çabalarını sürekli geliştiren öğrenen örgütler oluşturmak hedeflenmelidir (Robbins ve Judge ve Erdem, 2012, s. 604). Gerek eğitim alanında gerek işletmelerde kullanılan yazılım uygulamaları, simülasyonlar vb. bilgisayar destek sistemleri kişilerin işe uyumunu kolaylaştırmaktadır (Kommers, Stoyanov, Mileva ve Mediano, 2008, ss. 3-4). İşs stresiyle başa çıkma: Çalışanların sürdürülebilir bir biçimde iş stresinden kurtulma, stresi kontrol altında tutabilme ve diğer bireylere yansıtmama kabiliyetidir. Strese neden olan faktörleri, stresi önleme ve etki eden faktörleri azaltma yollarını farklı kültürdeki çalışanların algılarını da göz önünde bulundurarak tespit etmek ve gerekli uygulamaları gerçekleştirmektir (Robbins ve Judge ve Erdem, 2012, s. 618).

\section{Örneklem}

\section{Yöntem}

Araştırmanın örneklemi Kayseri organize sanayi bölgesi imalat sanayinde faaliyet gösteren iki işletmede çalışan toplam 273 kişiden kolayda örnekleme yöntemi ile oluşturulmuştur. Araştırma örnekleminin özel sektör ve sanayi alanından seçilmiş olmasının nedeni ise bu firmaların değişim ve dönüşümden etkilenme hızıdır. Ekonomik kalkınma ve gelişmişlik üzerinde büyük bir paya sahip olan sanayi kolu değişim ve dönüşümlerin çok hızlı gerçekleştiği dinamik bir yapıya sahiptir. Bu anlamda araştırma için sanayi sektörünün diğer sektörlerden görece daha çok uyuma gereksinim duyduğu düşüncesi araştırma örnekleminin belirlenmesine temel oluşturmuştur. Çalışmada kullanılan veriler yüz yüze anket yöntemi ile toplanmıştır. Bu iki işletme için toplam 250 anket dağlatılmış, bu anketlerden 205 tanesi geri dönmüş ancak 192 tanesi analizler için uygun bulunmuştur.

\section{Çeviri Çalışması}

Charbonnier-Voirin ve Roussel (2012) ölçeğinin araştırmada kullanılması ve Türkçe'ye uyarlanması için öncelikle ilgili ölçeğin ilk yazarı olan Audrey Charbonnier-Voirin'den elektronik posta ile yazılı izin alınmıştır. Orijinal dili İngilizce olan ölçeğin Türkçeleştirilmesinde, Brislin'in (1970) "Back Translation” tekniğinden yararlanılmıştır. Bu teknik kültürler arası araştırmalarda eşdeğer bir araç oluşturmak açısından sıklıkla kullanılmaktadır. Ölçek İngilizceye hakim üç bağımsız uzman tarafından orijinal dilden (İngilizce) hedef dile (Türkçe) çevrilmiştir. Daha sonra elde edilen Türkçe formlardaki ifadeler karşılaştırılarak değerlendirilmiş, anlaşılabilirlik ve uyumluluk göz önünde bulundurularak en uygun ifadelerle Türkçe form oluşturulmuştur. Türkçeye çevrilen ölçek maddelerinin ana dili Türkçe olan, uzun yıllardır yurtdışında yaşamış ve gerek akademik İngilizceye gerekse Türkçeye son derece hâkim birine gönderilerek yeniden İngilizceye çevrilmesi istenmiştir. Yeniden İngilizceye çevrilen maddeler orijinali ile karşılaştırılıp uygunluğu kontrol edilmiş ve ölçeğe son hali verilmiştir. 


\section{Veri Toplama Aracı}

$\mathrm{Bu}$ araştırma ile Charbonnier-Voirin ve Roussel'in (2012) geliştirdiği "Uyum Performansı" ölçeği Türk kültürüne ve Türkçeye uyarlanmaktadır. Toplam 19 ifadeden oluşan ölçek 5'li Likert tipinde derecelendirilmiş ve cevap seçenekleri; 1-Kesinlikle katılmıyorum, 2-Katılmıyorum, 3-Ne katılıyorum ne katılmıyorum, 4-Katılıyorum, 5-Kesinlikle katılıyorum şeklinde derecelendirilmiştir.

\section{Bulgular}

Katılımcıların \%62,7 si erkek, \%85,4'ü evlidir. \% 61,9 gibi büyük bir kısmı lise mezunu olup $\% 54,2$ 'si 36-45 yaş aralığında yer almaktadır. Yine katılımcıların \%82,4'ü üretim/teknik personel olarak çalışırken \%85,4'ünün unvanı departman departman/bölüm çalışanıdır.

\section{Güvenirlik Bulguları}

Uyum performansı ölçeğinin güvenirliliğini belirlemek adına Cronbach alfa iç tutarlılık katsayısı ve madde -toplam puan korelasyonu incelenmiştir. Ölçeğin tümü için hesaplanan alfa katsayısı 0,90 olarak bulunmuştur. Bu değer sosyal bilimler açısında oldukça yeterli görülmektedir. Uyum performansı ölçeğindeki maddelerin toplam puanı yordama ve ayırd ediciliğini belirlemek için yapılan madde analizine ilişkin madde-toplam puan korelasyonları Tablo'1 de yer almaktadır.

Tablo 1

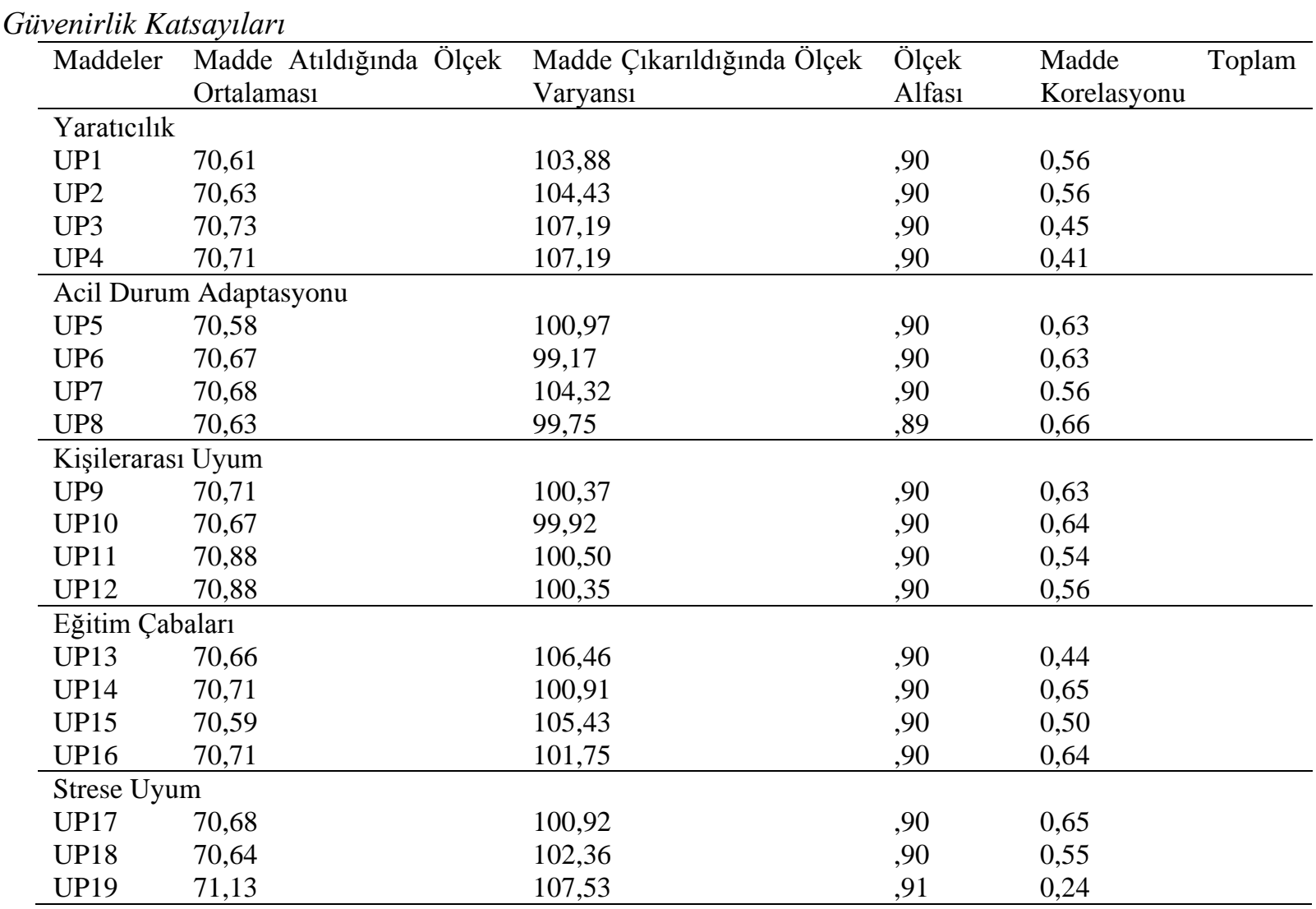

Tablo 1 incelendiğinde yaratıcılık boyutu için madde-toplam puan korelasyonlarının 0,560,41 aralığında, acil durum adaptasyonu boyutu için 0,63-0,56 aralığında, kişilerarası adaptasyon boyutu için 0,64-0,54 aralığında, eğitim çabaları boyutu için 0,65-0,44 aralığında değiştiği görülmektedir. Strese karşı adaptasyon alt boyutunun ilk iki maddesine ilişkin madde-toplam puan korelasyonları 0,65 ile 0,55 iken; strese karşı adaptasyon alt boyutunda yer alan bir ifadenin maddetoplam korelasyon değerinin 0,30 'dan küçük olması bu maddenin ölçülecek özelliği ayırt etme açısından yeterli kabul edilemeyeceğini göstermektedir (Büyüköztürk, 2003). Buna göre uyum 
performansı ölçeğinin alt boyutlarına ilişkin madde-toplam puan korelasyonlarının tutarlılı̆̆ının bir madde hariç, yeterli olduğu görülmektedir.

\section{Geçerlilik Bulguları}

Ölçeğin yapı geçerliliğinin doğrulanması adına açımlayıcı (AFA) ve doğrulayıcı (DFA) faktör analizi yapılmıştır. Faktör analizi, birbiriyle ilişkili çok sayıdaki maddelerin bir araya getirilerek, birbirleri ile tutarlı daha az sayıda faktör elde etmeyi ve maddelerin oluşturduğu yapıların örüntüsünü keşfetmeyi amaçlayan, çok değişkenli analizlerin genel adıdır (Kim ve Mueller, 1978). AFA daha çok ölçek geliştirme çalışmalarının ilk aşamasını oluştururken (Conway ve Huffcutt, 2003) DFA ise önceden geliştirilmiş ve önceki araştırmalarda kullanılmış veya kuramsal dayanağa sahip bir ölçeğin ya da modelin doğruluğunu belirlemeye çalışır (Brown, 2006).

\section{Açımlayıcı Faktör Analizi}

Çalışanların değişen durum ve koşullara uyum yeteneğini belirlemek amacıyla kullanılan ve toplam 19 maddeden oluşan uyum performansı ölçeği; yaratıcılık, acil durumlara adaptasyon, kişilerarası uyum, eğitim çabaları ve strese uyum olmak üzere beş boyuttan oluşmaktadır (Charbonnier-Voirin ve Roussel, 2012). Literatürde 5 boyut ile ifade edilen uyum performans1 ölçeğinin bilinen yapı ile uyumlu olup olmadığının belirlenerek yapı geçerliliğinin kontrolü faktör analizi ile yapılmıştır.

Uyum performansı ölçeğine ait verilerin faktör analizine uygunluğu KMO örneklem yeterliliği ve Barlett küresellik testi ile incelenmiştir. KMO değeri 0,788 olup, Barlett testi sonuçları da istatistiksel olarak anlamlı bulunmuştur $(\chi 2=3100.030$ ve $p<0.0001)$. Bu sonuçlar dikkate alındığında uyum performansı ölçeğine ilişkin verilere faktör analizi yapılmasının uygun olduğu belirlenmiştir. Ölçeğin faktör yapıları belirlenirken faktörleştirme yöntemlerinden temel bileşenler analizi, döndürme yöntemi olarak ise dik döndürme yöntemlerinden maximum değişkenlik (varimax) yöntemi tercih edilmiştir. Yapılan güvenirlik analizi sonucunda stresle başa çıkma boyutunda yer alan bir ifade çıkarılmıştır. Bu yüzden 18 ölçek maddesi analize tabi tutulmuştur. Analiz sonucunda 18 ölçek maddesi, ortak varyans ve faktör yükleri açısından değerlendirilmiştir. Faktörlerin mümkün olduğunca güçlü maddelerden oluşmasını sağlamak adına faktör yük değerlerinin 0,50 ve üzerinde olmasına dikkat edilmiştir (Nunnally, 1978; Gürbüz ve Şahin, 2014, s. 312).

Tablo 2

Uyum Performansı Ölçeği AFA Sonuçları

\begin{tabular}{|c|c|c|c|c|}
\hline & $\begin{array}{l}\text { Faktör } \\
\text { Yükü }\end{array}$ & Özdeğer & $\begin{array}{l}\text { Açılanan } \\
\text { Varyans \% }\end{array}$ & Ort. \\
\hline 1.Faktör: Acil Durum Adaptasyonu & & 6,517 & 40,730 & 3,36 \\
\hline $\begin{array}{l}\text { UP6. Problemleri çözmek için nasıl davranmam gerektiğine hızlı } \\
\text { bir şekilde karar veririm. }\end{array}$ &, 882 & & & \\
\hline $\begin{array}{l}\text { UP5. Hizlı hareket etmek için duruma tam olarak } \\
\text { odaklanabilirim. }\end{array}$ & ,878 & & & \\
\hline $\begin{array}{l}\text { UP8. Yeni koşullara uyum sağlamak için işimi kolayca tekrar } \\
\text { organize ederim. }\end{array}$ &, 817 & & & \\
\hline $\begin{array}{l}\text { UP7. En makul olanı seçmek için olası çözümleri ve etkilerini } \\
\text { hızlıca analiz ederim. }\end{array}$ &, 813 & & & \\
\hline 2. Faktör: Kişilerarası Uyum & & 2,451 & 15,318 & 3,32 \\
\hline $\begin{array}{l}\text { UP12. Diğerleriyle uyumlu çalışabilmek adına davranışlarımı } \\
\text { gönül rahatlığıyla değiştirebilirim. }\end{array}$ & ,935 & & & \\
\hline $\begin{array}{l}\text { UP11. Diğerleriyle iş birliği kurmak için işimi daha iyi yapmamı } \\
\text { sağlayacak yeni yollar öğrenirim. }\end{array}$ & ,930 & & & \\
\hline $\begin{array}{l}\text { UP10. İş arkadaşlarımla ilişkimi geliştirmek için onların bakış } \\
\text { açılarını anlamaya çalışırım. }\end{array}$ &, 890 & & & \\
\hline
\end{tabular}


UP9. İş arkadaşlarımla iyi ilişkiler geliştirmek etkinliğim ,727 açısından önemli bir faktördür.

\begin{tabular}{|c|c|c|c|c|}
\hline 3.Faktör: Yaratıcılık & & 1,80 & 11,280 & 2,98 \\
\hline $\begin{array}{l}\text { UP3. Yenilikçi bir çözüm sunmak için çeşitli kaynaklar/bilgi } \\
\text { türleri kullanırım. }\end{array}$ &, 845 & & & \\
\hline $\begin{array}{l}\text { UP2. Çalıştı̆̆ım departmanda/bölümde, yeni çözümler sunmam } \\
\text { konusunda insanlar bana güvenir. }\end{array}$ & 839 & & & \\
\hline $\begin{array}{l}\text { UP4. Yeni problemleri çözmek amacıyla yeni araç ve yöntemler } \\
\text { geliştiririm. }\end{array}$ &, 824 & & & \\
\hline $\begin{array}{l}\text { UP1. Yerleşmiş fikirlere karşı çıkmaktan ve yenilikçi çözümler } \\
\text { çıkmaktan çekinmem }\end{array}$ & ,785 & & & \\
\hline 4.Faktör: Eğitim Çabaları & & 1,703 & 10,642 & 2,80 \\
\hline $\begin{array}{l}\text { UP13. İş ile ilgili yeterli kalabilmek için iş içinde ya da iş dışında } \\
\text { düzenli olarak eğitim alırım. }\end{array}$ &, 850 & & & \\
\hline $\begin{array}{l}\text { UP15. Performansımı geliştirmemi sağlayan için her firsatı } \\
\text { kollarım (eğitim, grup projesi, meslektaşlarla fikir alışverişi vb.). }\end{array}$ & ,814 & & & \\
\hline $\begin{array}{l}\text { UP16. Her projeye ya da görevlendirmeye dahil olarak değişime } \\
\text { hazır olurum. }\end{array}$ & ,758 & & & \\
\hline $\begin{array}{l}\text { UP14.Çalışma şeklimi geliştirmek için işimle ilgili son } \\
\text { yenilikleri takip ederim. }\end{array}$ & ,713 & & & \\
\hline
\end{tabular}

Yapılan analiz sonrasında orijinal ölçekte yer alan stresle başa çıma boyutuna ilișkin maddelerden "UP19. Zor durumlarda her zaman meslektaşlarım benim tavsiyelerimi isterler." "UP17. Karar vermem gerektiğinde soğukkanlılı̆ğmı korurum." ve "UP18. Meslektaşlarımla sakin bir biçimde tartışarak çözüm ararım." ifadelerinin faktör yükü 0,30'un altında olduğu için analizden çıkarılmıştır. $\mathrm{Bu}$ bağlamda ölçeğin orijinal formunda yer alan dört boyutun (Acil durum adaptasyonu, kişilerarası uyum, yaratıcılık, eğitim çabaları) yapı geçerliliği belirlenmiştir. Analiz sonucunda özdeğeri 1'den büyük dört faktör boyutu elde edilmiş olup acil durum adaptasyonu faktörünün toplam varyans1 açiklama orana $\% 40,73$, kişilerarası uyum faktörünün $\% 15,31$, yaratıcılık faktörünün $\% 11,28$ ve son olarak eğitim çabaları faktörünün toplam varyansı açılama oranı \%10, 64'tür. Dört faktörün kümülatif olarak toplam varyansı açıklama oranı \%77,97 ile kabul edilebilir sınırlar içindedir.

\section{Doğrulayıcı Faktör Analizi}

Uyum performansı ölçeğinin faktör analizi ile belirlenen yapısının, elde edilen veriler ile uyumunun sınanması amacıyla doğrulayıcı faktör analizinden (DFA) yararlanılmıștır. DFA modelleri, gizil değişken modellerinin daha geniş bir sınıfını kapsayan YEM' in temel bir bileşenidir. Gözlenen değişkenlerle gizil yapılar arasındaki ilişkiyi ölçme modelleri ile tasvir eden bir YEM türü olarak kabul edilen analiz, ölçme modellerinin doğruluğunu sınamak için de kullanılmaktadır (Thompson, 2004, s. 109-110). Doğrulayıcı faktör analizinde uyum istatistikleri, modelin kabul edilip edilmeyeceğine dair bir takım kabul edilebilir sınır değerler kullanılarak yorumlanmaktadır. Daha açık bir ifadeyle, analiz sonucunda üretilen uyum istatistiklerinin belli değerlerin üzerinde veya altında olması istenir (Şimşek, 2007, s. 14).

Modelin geçerliğini test etmek için çok sayıda uyum indeksi kullanılmaktadır. Bunlar içinde en sık kullanılanları Ki-Kare Uyum Testi ( $\chi 2 /$ df), Karş1laştırmalı Uyum İndeksi (CFI- Comparative Fit Index), Düzeltilmiş İyilik Uyum İndeksi (AGFI- Adjusted Goodness-of-Fit-Index), Normlandırılmış Uyum İndeksi (NFI- Normed Fit Index), Fazlalık Uyum İndeksi (IFI- Incremental Fit Index) ve Yaklaşık Hataların Ortalama Karekökü (RMSEA- Root Mean Square Error of Approximation) dür. Buna göre CFI, AGFI, NFI, IFI, TLI'nın 0,90'dan büyük değerlerde olması yeterli düzeyde uyumun olduğunu göstermektedir. RMSEA değerlerinin ise 0,05 'ten küçük olmasının iyi uyumu, 0.10'un altında olması ise kabul edilebilir bir uyumu göstermektedir. Ki-kare değerinin serbestlik derecesine oranın ise 5'in altında olmasının iyi uyumu gösterdiği belirtilmektedir (Browne ve Gudeck, 1993; Çokluk, Şekercioğlu ve Büyüköztürk, 2010; Hu ve Bentler, 1999; Kline, 2005; MacCallum, Browne, and Sugawara, 1996; Marsh ve Hocevar, 1988; Marsh, Balla ve McDonald, 1988; Sümer, 2000; Tabachnick ve Fidell, 2007; Şimşek, 2007). 
Uyum performansı ölçeğinin, orijinal ölçekte bulunan faktör yapısı ile ne derece örtüştügünün sınanması ve bu sayede yapı geçerliliğine sahip olup olmadığının belirlenmesi amacıyla yapılan birinci düzey DFA'ya ilişkin sonuçlar Şekil 1'de yer almaktadır.

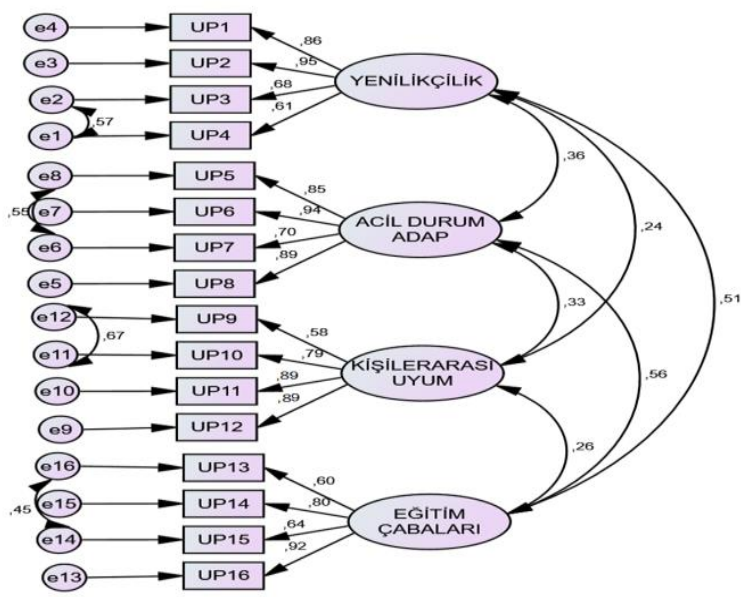

Şekil 1. Birinci Düzey Doğrulayıcı Faktör Analizi

Şekil 1'de görüldüğü gibi analiz sonucunda elde edilen standardize edilmiş regresyon katsayıları yenilikçilik boyutu için ,61 ile ,95 arasında; acil durumlara adaptasyon boyutu için ,70 ile 94 arasında; kişilerarası uyum boyutu için ,58 ile ,89 ve eğitim çabaları boyutu için ,60 ile ,92 arasında değişen değerler almaktadır. Yapılan analizde modifikasyon endeksleri incelendiğinde bazı maddelere ait hata terimlerinin ilişkilendirilmesinin modeli daha uyumlu hale getireceğini göstermektedir. $\mathrm{Bu}$ hata terimleri arasında kurulan ilişkiler yine şekil 1'de yer almaktadır.

YEM kapsamında oluşturulan birinci düzey doğrulayıc1 faktör modeline göre uyum performansını ölçmeye yönelik 16 ifade 4 boyutta modellenmiştir. Tablo 3 'te uygulanan birinci düzey doğrulayıcı faktör analizi ve modele ilişkin temel uyum indeksleri yer almaktadır.

Tablo 3

Yönetsel Beceriler Ölçeğine İlişkin Doğrulayıcı Faktör Analizi

\begin{tabular}{lllllllllll}
\hline Ölçek/ İndeksler & $\chi 2$ & $\mathrm{df}$ & $\mathrm{p}$ & $\chi 2 / \mathrm{df}$ & $\mathrm{CFI}$ & AGFI & NFI & IFI & TLI & RMSEA \\
\hline $\begin{array}{l}\text { S1k1lık-Esneklik } \\
\text { Ölçeği Tek Faktörlü } \\
\text { Modeli }\end{array}$ & 148,868 & 94 & .00 & 1,584 & 0,95 & 0,90 & 0,90 & 0,95 & 0,94 & 0.078 \\
\end{tabular}

Tablo 3'te DFA'dan elde edilen modelin uyum indeksleri incelenmiş ve minimum ki-kare değerinin $(\chi 2=148,868, \mathrm{df}=94, \mathrm{p}=0.00)$ anlamlı olduğu görülmüştür. Uyum indeksi değerleri ise RMSEA $=0.078, \mathrm{CFI}=0.95$, AGFI $=0.90, \mathrm{NFI}=0.90, \mathrm{IFI}=0,95$ ve $\mathrm{TLI}=0,94$ olarak bulunmuştur. $\mathrm{Bu}$ uyum indeksi değerleri dört faktörlü modelin kabul edilebilir olduğunu ortaya koymaktadır.

\section{Yapı Geçerliliği}

Tablo 4

Uyum Performansı Ölçeği Yapı Geçerliliği Sonuçları

\begin{tabular}{|c|c|c|c|c|c|c|}
\hline Ölçek Maddeleri & Std.yük & $\begin{array}{l}\mathrm{t}- \\
\text { değeri }\end{array}$ & $\mathrm{R}^{2}$ & $\begin{array}{l}\text { Yap1 } \\
\text { Güven. }\end{array}$ & $\begin{array}{l}\text { Açık. } \\
\text { Varyans }\end{array}$ & Ort. \\
\hline 1.Faktör: Acil Durum Adaptasyonu & & & & 0,93 & 0,76 & 4,00 \\
\hline $\begin{array}{l}\text { UP6. Problemleri çözmek için nasıl davranmam } \\
\text { gerektiğine hızlı bir sekilde karar veririm. }\end{array}$ & 0.94 & 13,87 & 0,88 & & & \\
\hline
\end{tabular}


UP5. Hizlı hareket etmek için duruma tam olarak odaklanabilirim.

UP8. Yeni koşullara uyum sağlamak için işimi kolayca tekrar organize ederim.

UP7. En makul olanı seçmek için olası çözümleri ve etkilerini hızlıca analiz ederim.
0.85

0.89

$11.50 \quad 0,72$

0.70

$12,34 \quad 0,79$

$8.12 \quad 0,49$

2. Faktör: Kişilerarası Uyum

UP12. Diğerleriyle uyumlu çalışabilmek adına davranışlarımı gönül rahatlığıyla değiştirebilirim.

UP11. Diğerleriyle iş birliği kurmak için işimi daha iyi yapmamı sağlayacak yeni yollar öğrenirim.

UP10. İş arkadaşlarımla ilişskimi geliştirmek için onların bakış açılarını anlamaya çalışırım.

UP9. İş arkadaşlarımla iyi ilişsiler geliştirmek etkinliğim açısından önemli bir faktördür.

$0.89 \quad 12,37 \quad 0,79$

$0.89 \quad 34,18 \quad 0,79$

$0.79 \quad 12,29 \quad 0,62$

$0.59 \quad 6,79 \quad 0,34$

\begin{tabular}{|c|c|c|c|c|c|c|}
\hline 3.Faktör: Yaratıcılık & & & & 0,92 & 0,74 & 3,96 \\
\hline $\begin{array}{l}\text { UP3. Yenilikçi bir çözüm sunmak için çeşitli } \\
\text { kaynaklar/bilgi türleri kullanırım. }\end{array}$ & 0.68 & 8,46 & 0,46 & & & \\
\hline $\begin{array}{l}\text { UP2. Çalıştı̆̆ım departmanda/bölümde, yeni } \\
\text { çözümler sunmam konusunda insanlar bana } \\
\text { güvenir. }\end{array}$ & 0.95 & 6,71 & 0,90 & & & \\
\hline $\begin{array}{l}\text { UP4. Yeni problemleri çözmek amacıyla yeni } \\
\text { araç ve yöntemler geliştiririm. }\end{array}$ & 0.61 & 7,52 & 0.37 & & & \\
\hline $\begin{array}{l}\text { UP1. Yerleşmiş fikirlere karşı çımaktan ve } \\
\text { yenilikçi çözümler çıkmaktan çekinmem }\end{array}$ & 0.86 & 6,59 & 0,74 & & & \\
\hline 4.Faktör: Eğitim Çabaları & & & & 0,789 & 0,67 & 3,97 \\
\hline $\begin{array}{l}\text { UP13. İş ile ilgili yeterli kalabilmek için iş } \\
\text { içinde ya da iş dışında düzenli olarak eğitim } \\
\text { alırım. }\end{array}$ & 0.60 & 6,17 & 0,36 & & & \\
\hline $\begin{array}{l}\text { UP15. Performansımı geliştirmemi sağlayan için } \\
\text { her firsatı kollarım (eğitim, grup projesi, } \\
\text { meslektaşlarla fikir alışverişi vb.). }\end{array}$ & 0.64 & 6,74 & 0.41 & & & \\
\hline $\begin{array}{l}\text { UP16. Her projeye ya da görevlendirmeye dahil } \\
\text { olarak değişime hazır olurum. }\end{array}$ & 0.92 & 6,78 & 0.85 & & & \\
\hline $\begin{array}{l}\text { UP14.Çalışma şeklimi geliştirmek için işimle } \\
\text { ilgili son yenilikleri takip ederim. }\end{array}$ & 0.80 & 8.88 & 0,64 & & & \\
\hline
\end{tabular}

Yap1 geçerliliğini sağlamak için her bir gözlenen değişkenin standart faktör yükü 0,5 'den büyük ve istatistiksel olarak anlamlı olması, yapı güvenirliğinin 0,7'den büyük olması ve her yapı için açıklanan varyansın 0,5'ten yüksek olması gerekmektedir (Hair ve Anderson, 1998). Tablo 4'te belirtilen değerler incelendiğinde, ölçeğin yapı geçerliliğini sağladığını söylemek mümkündür. Bununla birlikte diğer tüm değerlerin olması gereken değerlerin üstünde olduğu gözlenmiştir. $\mathrm{Bu}$ nedenle genel olarak ölçeğin yapı geçerliliğini sağladığını söylemek mümkündür.

\section{Boyutlara ilişkin Güvenirlik Analizi Sonuçları}

Yapılan geçerlilik testlerinin ardından uyum performansı ölçeğinin güvenirliliğinin yeniden hesaplanması adına Cronbach alfa iç tutarlılık katsayısı incelenmiştir. Ölçeğin tümü için hesaplanan alfa katsayısı 0.90 olarak bulunmuştur. Ölçeğin alt boyutlarına ilişkin hesaplanan güvenirlik katsayıları ise tablo 5'te yer almaktadır. 
Tablo 5

Güvenirlik Katsayıları

\begin{tabular}{ll}
\hline Faktörler & Cronbach Alpha \\
\hline Yenilikçilik & 0,88 \\
Acil Durum Adaptasyonu & 0,91 \\
Kişilerarası Uyum & 0,92 \\
Eğitim Çabaları & 0,85 \\
Toplam & 0,90 \\
\hline
\end{tabular}

Tablo 5 incelendiğinde uyum performansı ölçeğini oluşturan boyutlara ilişkin alfa iç tutarlılık katsayısının .92 ile .85 arasında değiştiği görülmektedir. Yine bu değerler ölçeğin yüksek derecede güvenilir olduğunu göstermektedir.

\section{Sonuç, Tartışma ve Öneriler}

Bu çalışmada Charbonnier-Voirin ve Roussel (2012) tarafından geliştirilmiş olan uyum performansı ölçeğinin güvenirlik ve geçerlik testleri yapılmıştır. Ölçeğin yap1 geçerliliğini incelemek amacıyla açımlayıcı faktör analizi ve doğrulayıcı faktör analizi uygulanmıştır. Yine ölçeğin güvenirliğini tespit etmek için yapı güvenirliği ve Cronbach alfa katsayısı hesaplanmıştır. Uyum performansı ölçeğinin yap1 geçerliğini belirlemek üzere yapılan faktör analizi sonucunda özdeğeri 1 'den büyük dört faktör boyutu elde edilmiştir. Bu boyutlardan acil durum adaptasyonu faktörünün toplam varyansı açıklama orana $\% 40,73$, kişilerarası uyum faktörünün $\% 15,31$, yaratıc1lı faktörünün $\% 11,28$ ve son olarak eğitim çabaları faktörünün toplam varyansı açıklama oranı \%10, 64' olarak bulunmuştur. Orijinal ölçekte yer alan stresle başa çıkma boyutunun ise faktör yüklerinin uygun referans değerlerin altında olduğu görülmüştür. Dört faktörün toplam varyansı açıklama oranı ise \%77,97 gibi yüksek bir değer almıştır. Yapılan doğrulayıcı faktör analizi sonucunda ölçeğin yapısal olarak geçerli olduğu görülmüştür (stresle başa çıkma alt boyutu hariç). DFA'dan elde edilen modelin uyum indeksleri incelendiğinde minimum ki-kare serbestlik derecesinin iyi düzeyde uyum iyiliği gösteren 1,58 olarak hesaplanmıştır. Bunun yansıra model uyum indekslerinden RMSEA=0.078, $\mathrm{CFI}=0.95, \mathrm{NFI}=0.90, \mathrm{IFI}=0,95$ ve $\mathrm{TLI}=0,94$ olarak bulunmuştur. Bu uyum indeksi değerleri ölçeğin dört faktörlü yapısının oldukça iyi bir uyum gösterdiğini ortaya koymaktadır. Yine yapı geçerliliğini belirlemek adına yapılan analizlerde genel olarak ölçeğin yapı geçerliliğini sağladığını göstermektedir. Araştırmanın bu sonucu Charbonnier-Voirin ve Roussel (2012, s. 285) tarafindan geliştirilen en kapsamlı ve detaylı performans ölçeğinden stres boyutu ile farklılaşmaktadır. Yine Han ve Williams (2008)'ın geliştirdikleri ölçekte (Acil durumlarla başa çıkma, yaratıcı problem çözme, belirsiz ve tahmin edilemeyen iş durumlarıyla ilgilenme ve iş stresiyle başa çıkma) dört boyutun doğrulandığ görülmektedir.

Orijinal ölçekte yer alan stresle başa çıkma boyutunu oluşturan üç ifade "UP19. Zor durumlarda her zaman meslektaşlarım benim tavsiyelerimi isterler." "UP17. Karar vermem gerektiğinde soğukkanlılığımı korurum." ve "UP18. Meslektaşlarımla sakin bir biçimde tartışarak çözüm ararım.” şeklindedir. Charbonnier-Voirin vd'nin (2012) Fransız katılımcılardan elde ettikleri veriler ile Türk katılımcılardan elde edilen sonuçların farklılaşması sosya ekonomik ve demografik farklılıklarla açıklanabilir. Hofstede'in (1980 ve 1983) toplumsal kültüre ilişkin yaptığı çalışmalar göz önünde bulundurulduğunda elde edilen bu farklı sonuç daha da anlaşılır olmaktadır. Her toplumun kendine özgü bir takım değer ve davranışlara sahip oluşu, yine Türk kültüründe çalışanların strese maruz kalma sıklığı, yaşam şartları ve koşulların değişkenliği elde edilen bu farklı sonucun nedenleri arasında sıralanabilir. Yine Açıkgöz (2015, s. 39) "Bilişim endüstrisinde adaptasyon ve ürün başarısı: Çok katmanlı bir çalışma" başlıklı çalışmasında uyum performansı ölçeğini Türkçeleştirmiş bu çalışmaya paralel olarak ölçeğin kriz yönetimi, yaratıcı problem çözme, öğrenme ve bireyler arası adaptasyon olarak dört boyuta sahip olduğunu tespit etmiştir.

Yapılan güvenirlik analizleri sonucunda ölçeğin bütünü için hesaplanan güvenirlik katsayısı 0,90 olarak bulunmuştur. Alt boyutlar bazında ise yenilikçilik için bu değer 088; acil durum adaptasyonu 0,91 ; kişilerarası uyum 0,92 ve son olarak eğitim çabaları 0,85 olarak hesaplanmıştır. 
Tüm bu analizler sonucunda, uyum performansı ölçeğinin içsel tutarlılığının oldukça yüksek ve güvenilir bir ölçek olduğunu ortaya koymaktadır. $\mathrm{Bu}$ bağlamda uyum performansı ölçeğinin Türkiye'deki ilgili araştırmalarda kullanılabilir bir ölçek olduğu düşünülmektedir. Bireysel, örgütsel ve takım seviyesinde birçok kavramla ilişki içerisinde olduğu çeşitli araştırmalar ile tespit edilen uyum performansı kavramının yerli yazında gereken ilgi ve değeri görmediğini söylemek gerekmektedir. Türkçe'ye uyum çalışmaları yapılan bu ölçek sayesinde kavrama ilişkin birçok noktanın aydınlatılacağı ve gereken ilgiyi göreceği umulmaktadır. Bu anlamda uyum performansının çeşitli örgütsel süreç ve çıktılar ile ilişkisini belirlemeye yönelik yapılacak çalışmaların literatüre katkı sağlayacağı düşünülmektedir.

Uyum günümüz işletmelerinin sürekli değişen ve dönüşen iş çevresinde, ayakta kalma ve rekabetle başa çıkmada kilit bir role sahiptir. Yabancı literatürde ve örgütsel yazında durumsallık kuramı ile birlikte araştırmacıların dikkatini cezbeden uyum kavramının işletmeler bağlamında ele alınarak örgütlere nasıl katkılar sağlayacağının araştırılması faydalı olacaktır. Uyum performansı işin gereklerinden kaynaklanan değişikliklere odaklanmayı ifade ederken, görev performansı günlük görevler ile ilgilenmektedir. Uyum performansı görev performansından farklı olarak sürekli kullanılan bir yeteneği ifade etmektedir. Görevin içeriği ve koşulları değiştiğinde uyum performansı yüksek çalışanların işlerini daha kolay yürütebileceği söylenebilir. Yine uyum performansının görev performansına göre daha kapsayıcı ve uluslararası geçerliliğe sahip (Allworth ve Hesketh, 1999, s. 98) olduğu düşünüldüğünde kavramın önemi artmaktadır. Tüm bu açıklamalar doğrultusunda çalışanların iç ve dış çevrenin değiş̧ken koşullarına uyum sağlama becerisini ifade eden uyum performansına ilişkin becerilerin örgütlerce göz önünde bulundurulması gerektiği düşünülmektedir.

Örgütlerde yaşanan değişim, dönüşüm ve rekabet şartlarından kaynaklanan hızlı gelişmeler uyum performansının önemini günden güne artırmaktadır. Bu anlamda araştırma ile örgütler için çok önemli bir kaynak niteliğinde olan insan kaynağının performansını değerlendirme çalışmalarında tam ve doğru kararlar verilmesine yardımcı olacak ve yol gösterecek alternatif bir yeteneğe dikkat çekilmektedir. Görev ve sonuç odaklı değerlendirilen çalışanların süreç odaklı değerlendirildiklerine ve sahip oldukları farklı yeteneklerin görünür olduğuna ilişkin sahip olacakları olumlu algıları örgütleri rakipleri karşısında bir adım öteye taşıyacaktır. Yönetici ve uygulayıcıların çalışanları değerlendirmede uyum performansını da dâhil ettikleri bir sistem oluşturmaları daha bütüncül ve yapıcı bir performans değerlendirmeye olanak sağlayacaktır.

Literatürde uyum performansının çeşitli örgütsel değişken ver süreçler ile birlikte ele alındığı bilinmektedir. Örneğin Monteiro (2015, s. 18) kavram ile iş güvensizliği, işten ayrılma stresi ve tükenmişlik stresi negatif ilişkilere odaklanırken; Açıkgöz (2015, s. 39) kavram ile çalışanların örgütsel adaptasyon becerileri üzerine çalışmıştır. Evrenosoğlu (2007) çalışmasında talep-yetenek yaklaşımı açısından birey iş uyumu, ihtiyaç-arz yaklaşımı açısından birey-iş uyumu ve birey-değer uyumunu ölçmüştür. Çelik, Turunç ve Demirkaya (2011) adaletin performans üzerine etkisinde kişi örgüt uyumunun aracılık rolünün bulunup bulunmadığını belirlemeye yönelik yaptıkları çalışmalarında, kişi örgüt uyumunun iş performansı üzerinde pozitif yönde bir etkisinin bulunduğunu; algılanan adaletin boyutlarının ise iş performansı üzerine etkisinde kişi örgüt uyumunun aracılık rolünün bulunmadığını belirlenmiştir. Yine araştırmanın önemli bir bulgusu da, algılanan adalet boyutlarının kişi-örgüt uyumu üzerinde anlamlı etkisinin görülmesidir. Son olarak Jundt, Shoss ve Huang (2015, s. 67) uyum performansının stresi azaltıp, iyi oluş halini artırdığını belirtmiştir. Ölçeğin Türkçeye çevrilmesi ile bahsi geçen çalışmaların Türkiye bağlamındada yürütelebilineceği

Her araştırmada olduğu gibi bu araştırmada da çeşitli kısıtlar bulunmaktadır. Bu araştırmanın en önemli kısıtı yalnızca sanayi alanında ve iki işletmeden elde edilen veriler ile gerçekleştirilmiş olmasıdır. Bu anlamda araştırma kapsamında Türkçeleştirilen bu ölçeğin diğer sektörler ve çalışma alanlarında örgütsel birtakım değişkenlerle ilişkilendirilerek kullanılması ile alan yazına önemli katk1lar sunulacaktır. 


\section{Kaynaklar}

Açıkgöz, A. (2015). Bilişim endüstrisinde adaptasyon ve ürün başarısı: Çok katmanlı bir çalışma. Istanbul University Journal of the School of Business, 44(2), 39-55.

Ahmad, S. and Schroeder, R. G. (2003). The impact of human resource management practices on operational performance: Recognizing country and industry differences. Journal of Operations Management, 21(1), 19-43.

Allen, R. C., Fontaine, J. J., Pope, L. K. and Garmestani, S. A. (2011). Adaptive management for a turbulent future. Journal of Environmental Management, 92(5), 1339-1345.

Allworth, E. and Hesketh, B. (1999). Construct-oriented biodata: Capturing change-related and contextually relevant future performance. International Journal of Selection and Assessment, 7 (2), 97-111.

Baard, K. S. Rench, A. T. and Kozlowski W. J. S. (2014). Performance adaptation: A theoretical integration and review, Journal of Management, 40(1), 48-99.

Borman, C. W. and Stephen J. M. (1993). Expanding the criterion domain to include elements of contextual performance. Schmitt W. C. and Borman W. C. (Eds.), Personnel selection in organizations. San Francisco, Jossey Bass: CA.

Brislin, R. W. (1970). Back-translation for cross-cultural research. Journal of cross-cultural psychology, 1(3), 185-216.

Brown, A. T. (2006). Confirmatory factor analysis: For applied research. New York: Guilford Press.

Browne, W. Michael W. and Cudeck, R. (1993). Alternative ways of assessing model fit. Bollen K. A. and Long J. S. (Eds.), Testing structure equation models (p. 136-162). Newbury Park, CA.

Büyüköztürk, Ş. (2003). Sosyal bilimler için veri analizi el kitabı. Ankara: PegemA Yayıncılık.

Champbell, P. J. (1999). The definition and measurement of performance. Ilgen, D. R. and Pulakos, E. D. (Eds.), The changing nature of performance (p. 399-429).San Francisco: Josey-Bass Publishers.

Charbonnier-Voirin, A., Assâad El A. and Vandenberghe C. (2010). A multilevel model of transformational leadership and adaptive performance and the moderating role of climate for innovation. Group and Organization Management, 35(6), 699-726.

Charbonnier-Voirin, A. and Roussel, P. (2012). Adaptive performance: A new scale to measure individual performance in organizations. Canadian Journal of Administrative Sciences/Revue Canadienne des Sciences de l'Administration, 29(3), 280-293.

Chen, G., Brian, T. and Wallace C. J. (2005). A multilevel examination of the relationships among training outcomes, mediating regulatory processes, and adaptive performance. Journal of Applied Psychology, 90(5), 827-841.

Conway, J. M. and Huffcutt, I. A. (2003). A review and evaluation of exploratory factor analysis practices in organizational research. Organizational research methods, 6(2), 147-168.

Çetinkaya, F. ve Gülbahar, H. (2019). Stratejik yönetim ve inovasyon ilişkisi: Kobi’ler üzerine bir araştırma. Ahi Evran Üniversitesi Sosyal Bilimler Enstitüsü Dergisi, 5(2), 367-349. 
Çokluk, Ö., Şekercioğlu, G. ve Büyüköztürk, Ş. (2010). Çok değişkenli istatistik SPSS ve LISREL uygulamaları. Ankara: Pegem Akademi Yayınları.

Didin, K. (2017). The mediating roles of trust and value congruence on the relationship between transformational leadership and adaptive performance. Russian Journal of Agricultural and Socio-Economic Sciences, 64(4), 126-132.

Drewery, D., Nevison, C., Pretti, T. J. and Pennaforte, A. (2017). Lifelong learning characteristics, adjustment and extra-role performance in cooperative education. Journal of Education And Work, 30(3), 299-313.

Griffin, B. and Hesketh, B. (2003). Adaptable behaviours for successful work and career adjustment. Australian Journal of psychology, 55(2), 65-73.

Grotto, A. R., Hyland, P. K., Caputo, A. W. and Semedo, C. (2017). Employee turnover and strategies for retention. The Wiley Blackwell Handbook of the Psychology of Recruitment, Selection and Employee Retention, 443-472.

Gürbüz, S. ve Şahin, F. (2014). Sosyal bilimlerde araştırma yöntemleri. Ankara: Seçkin Yayıncılık.

Han, T. Y. and Williams, K. J. (2008). Multilevel investigation of adaptive performance: Individualand team-level relationships. Group and Organization Management, 33(6), 657-684.

Hesketh, B. and Neal, A. (1999). Techonology and performance. Ilgen, R. D. ve Pulakos, D. E. (Ed.), The changing nature of performance (p.21-55). San Francisco: Josey-Bass Publishers.

Hofstede, G. (1980). Culture's consequences: International differences in work-related values. Beverly Hills, CA: Sage Publications.

Huang, J. L., Ryan, A. M., Zabel, K. L. and Palmer, A. (2014). Personality and adaptive performance at work: A meta-analytic investigation. Journal of Applied Psychology, 99(1), 162-179.

Ilgen, R. D. and Pulakos, D. E. (1999). Employee performance in today's organizations. Ilgen, D. R. and E. D. Pulakos (Eds.), The Changing nature of performance. San Francisco: Josey-Bass Publishers.

Jawahar, I. M., and Carr, D. (2007). Conscientiousness and contextual performance. Journal of Managerial Psychology, 22(4), 330-349.

Jong, A. D., and De Ruyter, K. (2004). Adaptive versus proactive behavior in service recovery: The role of self-managing teams. Decision Sciences, 35(3), 457-491.

Joung, W., Hesketh, B., and Neal, A. (2006). Using "war stories" to train for adaptive performance: Is it better to learn from error or success?. Applied psychology, 55(2), 282-302.

Jundt, D. K., Shoss, M. K., and Huang, J. L. (2015). Individual adaptive performance in organizations: A review. Journal of Organizational Behavior, 36(1), 53-71.

Kim, J. O., and Mueller, C. W. (1978). Factor analysis: statistical methods and practical issues. Beverly Hills, CA: Sage.

Kline, B. R. (2005). Principles and practice of structural equations modeling. New York: Guilford.

Kommers, P., Stoyanov, S., Mileva, N. and Mediano, C. M. (2008). The effect of adaptive performance support system on learning achievements of students. International Journal of Continuing Engineering Education and Life Long Learning, 18(3), 351-365. 
Koopmans, L. (2014). Measuring individual work performance. Journal of Occupational and Environmental Medicine, 53(8), 856-866. DOI: 10.1097/JOM.0b013e318226a763.

Kozlowski, S. W. and Bell, B. S. (2003). Work groups and teams in organizations. Handbook of psychology, 333-375.

Kozlowskı, S. W., Gully, S. M., Brown, K. G., Salas, E., Smith, E. M. and Nason, E. R. (2001). Effects of training goals and goal orientation traits on multidimensional training outcomes And performance adaptability. Organizational Behavior and Human Decision Processes, 85(1), 1-31.

Lepine, J. A., Colquitt, J. A., and Erez, A. (2000). Adaptability to changing task contexts: Effects of general cognitive ability, conscientiousness, and openness to experience. Personnel psychology, 53(3), 563-593.

Lim, D. H., Yoo, M. H., Kim, J., and Brickell, S. A. (2017). Learning agility: The nexus between learning organization, transformative learning, and adaptive performance. Adult Education Research

Conference, https://newprairiepress.org/cgi/viewcontent.cgi?referer=https://scholar.google.com/Andhttpsre $\operatorname{dir}=1$ Andarticle $=3873$ Andcontext $=$ aerc

Maccallum, R. C., Browne, M. W. and Sugawara, H. M. (1996). Power analysis and determination of sample size for covariance structure modeling. Psychological methods, 1(2), 130-149.

Marsh, H. W. and Hocevar, D. (1988). A new, more powerful approach to multitrait-multimethod analyses: Application of second-order confirmatory factor analysis. Journal of Applied Psychology, 73(1), 107-117.

Marsh, H. W., Balla, J. R. and Mcdonald, R. P. (1988). Goodness-of-fit indexes in confirmatory factor analysis: The effect of sample size. Psychological bulletin, 103(3), 391-410.

Monteiro, A. (2015). The impact of job insecurity on adaptive performance via burnout. Doctoral dissertation. School of Business And Economics.

Nunnally, C. J. (1978). Psychometric theory. New York: McGraw-Hill.

Oliver, T. and Lievens, F. (2014). Conceptualizing and assessing interpersonal adaptability: Towards a functional framework. In Individual adaptability to changes at work (p. 78-98). Routledge.

Oolders, T., Chernyshenko, O. S. and Stark, S. (2008). Cultural intelligence as a mediator of relationships between openness to experience and adaptive performance. Handbook of cultural intelligence: Theory, measurement, And applications, 145-158.

Özdemir H. (2019). Konaklama işletmelerinde çalışan personelin örgütsel bağl1lıklarının çeşitli açılardan incelenmesi. Ahi Evran Üniversitesi Sosyal Bilimler Enstitüsü Dergisi, 5(2), 250237.

Ployhart, R. E. and Blaese, P. D. (2006). Individual adaptability (I-ADAPT) theory: Conceptualizing the antecedents, consequences, and measurement of individual differences in adaptability. In UnderstAnding adaptability: A prerequisite for effective performance within complex environments. (p.3-39). Emerald Group Publishing Limited.

Pulakos, E. D. (2009). Performance management: A new approach for driving business results. John Wiley and Sons. 
Pulakos, E. D., Arad, S., Donovan, M. A. and Plamondon, K. E. (2000). Adaptability in the workplace: Development of a taxonomy of adaptive performance. Journal of applied psychology, 85(4), 612-624.

Pulakos, E. D., Dorsey, D. W. and White, S. S. (2006). Adaptability in the workplace: Selecting an adaptive workforce. In UnderstAnding adaptability: A prerequisite for effective performance within complex environments. Emerald Group Publishing Limited.41-71.

Pulakos, E. D., Schmitt, N., Dorsey, D. W., Arad, S., Borman, W. C. and Hedge, J. W. (2002). Predicting adaptive performance: Further tests of a model of adaptability. Human performance, 15(4), 299-323.

Robbins, S. and Judge, A. T. (2012). Örgütsel Davranış. Erdem. İ (Ed.), İstanbul: Nobel.

Sezgin, F. (2003). Kriz yönetimi. Manas Sosyal Bilimler Dergisi, 4 (8), 181-195.

Shoss, M. K., Witt, L. A. and Vera, D. (2012). When does adaptive performance lead to higher task performance?. Journal of organizational behavior, 33(7), 910-924.

Sonnentag, S., Volmer, J. and Spychala, A. (2008). Job performance. The Sage Handbook Of Organizational behavior, 1, 427-447.

Stokes, C. K., Schneider, T. R. and Lyons, J. B. (2008). Predicting adaptive performance in multicultural teams: a causal model (No. RTO-MP-HFM-142). Wright State Univ Dayton Oh.

Stokes, C. K., Schneider, T. R. and Lyons, J. B. (2010). Adaptive performance: A criterion problem. Team Performance Management: An International Journal. 16, 3/4 212-230.

Sümer, N. (2000). Yapısal eşitlik modelleri. Türk Psikoloji Yazıları, 3 (6): 49-74.

Şahin, F. ve Gürbüz, S. (2014). Cultural intelligence as a predictor of individuals' adaptive performance: A study in a multicultural environment. International Area Studies Review, 17(4), 394-413.

Şimşek, M. Ş. ve Çelik, A. (2011). Yönetim ve organizasyon. Eğitim Kitabevi.

Şimşek, Ö. F. (2007). Yapısal eşitlik modellemesine giriş: temel ilkeler ve LISREL uygulamaları. Ankara: Ekinoks.

Tabachnick, G. B. and Fidell, S. L. (2007). Using multivariate statistics. Boston: Allyn and Bacon.

Thompson, B. (2004). Exploratory and confirmatory factor analysis: Understanding concepts and applications. Washington, DC, US: American Psychological Association.

Çelik, M., Turunç, Ö., ve Demirkaya, H. (2011). Çalışanların adalet algılarının iş performansına etkisinde kişi örgüt uyumunun aracılık rolü: Turizm sektöründe görgül bir çalışma. Seyahat ve Otel Işletmeciliği Dergisi, 8(2), 40-57.

Uyargil, C. (2013). Performans değerlendirme. İnsan Kaynakları Yönetimi, 7, 211-266.

Uyargil, C., Adal, Z., Ataay, İ. D., Acar, A. C., Özçelik, A. O. Dündar, G. Ö. Sadullah ve Tüzüner, L. (2009). İnsan kaynakları yönetimi. 4. Baskı. Beta Basım: İstanbul.

Yüksel, Ö. (2006), Davranış bilimleri. Gazi Kitabevi: Ankara. 


\section{Extended Abstract}

Today, no matter how good the financial resources in an organization are, the probability of success will be very low if the human resource does not have sufficient efficiency. In this regard, adaptive performance, which is considered as a performance dimension different from task and contextual performance, has been defined as learning new tasks, the way of approaching these tasks, flexibility and coping with change (Hesketh \& Neal, 1999, pp. 46-47). Employees need a tolerant and versatile adaptability to uncertainty in order to maintain their effectiveness and efficiency in variable and difficult-to-estimate environmental conditions (Ilgen \& Pulakos, 1999, p. 14; Kozlowski \& Bell, 2003, p. 4; Pulakos, Arad, Donovan and Plamondon, 2000, p. 612). The ability of employees to adapt to different and new conditions, which is considered as a source that creates difference and is impossible to be imitated, also has a great importance on the competitiveness of organizations and their ability to sustain their existence.

Although the importance of adaptive performance, which expresses the projected or actual changes reflected in the behavior, is known to all (Shoss, Witt, and Vera, 2012, p. 911), it is seen that the adaptation and adaptive performance has been studied relatively little in the literature. It is not wrong to say that the more changes there are, the more adaptation is required. As it can be seen from the studies in the literature on adaptive performance, the concept gains importance day by day. It can be said that the concept will continue to find its place in the field with an expanding perspective at the individual, team and organizational level. With this study, it is aimed to introduce managers and practitioners with an alternative and new performance evaluation criteria. In this way, a multidimensional and holistic performance evaluation system which takes into account the adaptive performance as well as the contextual and task performance can be created. Introducing the concept of "Adaptive Performance" to the Turkish literature, providing a detailed literature review on the concept and providing a new and different instrument that will contribute to determining the relationship of the concept with the possible organizational outputs and results by conducting the Turkish reliability and validity study of the adaptation performance scale constitutes another purpose of the study, as well. In this way, by looking at the performance in a wider perspective, it is aimed to help the concept of (relatively neglected) adaptive performance to be included more in scientific studies.

\section{Methodology}

The sample of the study was formed by simple random sampling method from 273 people working in two companies operating in the manufacturing industry of Kayseri Organized Industrial Zone. The reason why the research sample was chosen from the private sector and industry is the speed at which these companies are affected by change and transformation. In this sense, the idea that the industry sector needs relatively more adaptation than other sectors formed the basis of the research sample. The data used in the study were collected by face-to-face survey method. A total of 250 questionnaires were distributed for these two enterprises, 205 of them were returned, but 192 were found suitable for analysis. With this research, the "Adaptive Performance" scale developed by Charbonnier-Voirin and Roussel (2012) is adapted to Turkish culture and Turkish. The scale consisting of a total of 19 expressions is rated as 5-point Likert type.

\section{Findings}

\section{Reliability Findings}

In order to determine the reliability of the adaptive performance scale, Cronbach alpha internal consistency coefficient and item-total correlation were examined. As a result of the analysis, the itemtotal correlations ranged from 0.56 to 0.41 for the creativity dimension, from 0.63 to 0.56 for the emergency adaptation dimension, from 0.64 to 0.54 for the interpersonal adaptation dimension and from 0.65 to 0.44 for the training efforts dimension. While the item-total correlations for the first two items of the stress adaptation sub-dimension were 0.65 to 0.55 , the fact that the item-total correlation 
value of an expression in the stress adaptation sub-dimension was less than 0.30 shows that it can not be accepted as sufficient in distinguishing the item to be measured (Büyüköztürk, 2003).

\section{Validity Findings}

In order to verify the construct validity of the scale, exploratory (EFA) and confirmatory (CFA) factor analysis were performed. As a result of the exploratory factor analysis, four factor dimensions with eigenvalues greater than 1 were obtained and the total variance explanation rate of the emergency adaptation factor was $40,73 \%$, the interpersonal adaptation factor was $15,31 \%$, the creativity factor was $11,28 \%$, and finally the training efforts factor was $10,64 \%$. The cumulative total variance disclosure rate of the four factors is within acceptable limits with $77.97 \%$. The fit indices of the model obtained from the CFA were examined and it was found that the minimum chi-square value $(\chi 2=148,868, \mathrm{df}=94, \mathrm{p}=0.00)$ was significant. The fit index values were found as RMSEA $=0.078$, $\mathrm{CFI}=0.95, \mathrm{AGFI}=0.90, \mathrm{NFI}=0.90, \mathrm{IFI}=0.95$ and $\mathrm{TLI}=0,94$. These fit index values reveal that the four-factor model is acceptable (Hair and Anderson ,1998).

\section{Result}

In this study, it was tried to determine the reliability and validity of the adaptive performance scale developed by Charbonnier-Voirin and Roussel (2012). As a result of the research, it was seen that the internal consistency of the adaptive performance scale is quite high. In this context, the adaptive performance scale is considered to be used in the relevant studies in Turkey. It is necessary to say that the concept of compliance performance, which has been determined to be related to many concepts at individual, organizational and team level through various studies, does not draw the required interest and value in the domestic literature. It is hoped that thanks to this scale, which has been adapted to Turkish, many points regarding the concept will be illuminated and the concept will draw the necessary attention. In this sense, it is thought that the studies to determine the relationship between adaptive performance and various organizational processes and outputs will contribute to the literature. 